\title{
Olympic Art Competition in Hungary
}

\author{
Ádám Rixer \\ Károli Gáspár University of the Reformed Church in Hungary, \\ Professor, Head of Depertment of Administrative Law
}

\begin{abstract}
The present study raises the idea of creating an artistic Olympics to facilitate further scientific, professional and, where approriate, broader social dialogue, taking two dimensions into consideration. On the one hand, it intends to support the realisation of an event of this type in Hungary while articulating valid arguments to emphasise those elements that would make Hungary an ideal organiser. On the other hand, the study offers indicators for further and more thorough scientific examination of the process by outlining the main research directions and methods.
\end{abstract}

Keywords: art, competition, Hungary, Olympics

\section{INTRODUCTION}

\section{The Purpose and Object of the Study and Potential Future Research}

The study hereby proposes the delivery of an Olympic art competition in Hungary and intends to prepare a highly detailed plan for such a competition. The study contributes to these purposes in two ways. Firstly, it enumerates and unfolds the reasons that motivate considering such an idea. Secondly, it exposes in detail the themes to be elaborated and the viewpoints to be considered by the preliminary feasibility studies, which need to have a scientific character, as well as the viewpoints to be considered later by the actual competition regulations. It is vital for the latter point that the background studies preparing and grounding the decisions related to actual execution should be divided according to various scientific domains and expressly artistic domains, i.e. preliminary cataloguing of the domains in the scope of the research.

\section{Historic background}

Even though an Olympic art competition has not been organised before, in Hungary or any other country, there are still relevant historical antecedents. Plato, the idealistic ancient philosopher, drew attention to the special binarity of physical and spiritual abilities, affirming that every Greek needed to attempt to develop himself simultaneously in both areas. ${ }^{1}$ In the literature of the Olympic Games, this educational model is called kalokagathia, inspired by an expression accepted in Greek philosophy, making reference to the idea that a healthy body and flawless morals are closely related. Under the aegis of the latter, intellectual and art competitions were also organised at the ancient Olympic Games alongside the sports competitions. Competitors included, for example, Herodotus, reading from his historical works, and Myron and Praxiteles, who offered their sculptures to be admired by the general public. ${ }^{2}$

\footnotetext{
${ }^{1}$ KeRESZTÉLYI József: Az Olimpiák története - Az Olümpiától Moszkváig (The History of the Olympic games - from Olympia to Moscow). Gondolat Kiadó. Budapest, 1980. 59.

2 TAKÁcs Ferenc: Az Olimpiák - múltja, jelene, jövője (The Olympic Games - Past, Present and Future). Magyar Olimpiai Bizottság. Budapest, 2012. 105. See also: LÉVAI György-IVANICs Tibor: Az újkori olimpiák története: 2. rész (1920-1936) (The History of the Modern Olympic Games. Part 2. 1920-1936). Kossuth Kiadó, Budapest, 2011.; and Findling, John E. - PElle, Kimberly D.: Encyclopedia of the Modern Olympic Movement. Greenwood Press, Westport. 2004.
} 
In 1905, ten years after the modern Olympic movement started, Pierre de Coubertin proposed - allegedly having been given the idea by the Hungarian Ferenc Kemény ${ }^{3}$ - that arts should be made part of the Olympic festivities in the same manner as in the times of the ancient Olympic Games. At the suggestion of Coubertin, who was at that moment the president of the International Olympic Committee, the art competition was organised in 1912 in Stockholm. An important criterion of the works of art presented was that they should be themed around sports, playing sports and social issues related to sports.

The first three modern Olympic art competitions (1912, 1920 and 1924) were organised in five artistic categories - literature, sculpture, painting, architecture and music. During the 1928 Olympics of Amsterdam there were subdivisions in architecture, (separate competitions were organised in the fields of stadium, sports park and civic design), literature (poetry, drama, epics) and sculpture (sculptures, reliefs). Further subdivisions were created at the 1936 Olympics, in music (orchestral work, voice, solo instrument) and painting (aquarelle, graphics, oil and water colour, engraving and etching). ${ }^{4}$

Artistic programmes, with medal awarding, were part of all seven Olympics competitions until the 1948 Games in London, yet these programmes and medals were not recognised by the International Olympic Committee as official events, i.e. as individual sports and medals.

Exclusion of the art competition from the Olympics programme happened due to several concurrent reasons. Evaluation of the achievements contained too many subjective elements, which sometimes caused heated debates ${ }^{5}$, and achievements (products) created during the Olympic Games and the authors (creators) themselves were evaluated also from an economic point of view - since there was no explicit regulation, this led to ethical conflicts.

Artistic aspects have been present at every later Olympics, but these have been merely unofficial secondary events - modern art exhibitions related to the history of the Olympic Games or to the theme of sports $^{6}$, or festival-like musical and other entertainment programmes, whose individual elements have in common only the fact that all have taken place during the Olympic Games (either at the location of the Games or elsewhere).

\section{FACTORS THAT MAKE THE SUCCESS OF SUCH AN EVENT PLAUSIBLE IN HUNGARY}

Naturally, besides the fact that such an event is uplifting as an idea for all people with an artistic and/or competitive mindset, to be able to decide whether such a proposal is worth considering seriously, some factors need to be catalogued in advance. These include potential consumer demand, financial aspects and basic considerations regarding the country's image. First, we shall consider which viewpoints make the success of such an event plausible.

1. The most practical reason has already been mentioned: this 'programme type' has some successful antecedents. Learning from earlier experiences makes it possible that former problems - primarily moral issues that earlier had not been clarified and the lack of concrete legal background - could be solved, especially if particular aspects unique to the Olympic art competition can emerge, i.e. this event does not intermingle in every

\footnotetext{
${ }^{3}$ http://www.mob.hu/nyari-olimpiai-jatekok/1948-london (2016.07.01.)

4 TAKÁCS op. cit. 106.

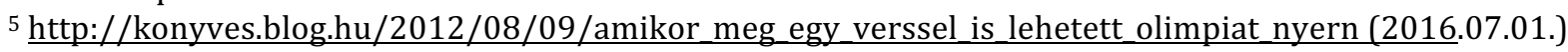

${ }^{6}$ Examples of the latter were also seen at the latest Olympic Games in Rio. See for example http://www.rainhart.net/en/olympics-games-2016/rio-2016-olympics-art-exhibition-description.html (2016.08.01.)
} 
aspect with the summer or winter Olympics and their specific system of conditions and regulations.

2. Attempts at similar, i.e. competition-like, artistic events have previously been organised in Hungary (and in other countries) in many artistic fields, but these are isolated or irregular events, or they function as festivals. [In Hungary a good example of an irregular event is the Liszt Ferenc International Piano Competition and festivals include the Budapest Spring Festival and the Budapest Dance Festival (neither of the latter is a competition).]

In Hungary and elsewhere there are also events that exhibit creations from several artistic fields (typically in the graphic arts) at the same time. But these are either market-oriented events with a narrow theme and without any specialist entertainment programmes, which last for only a few days, (e.g. Antik Interior in Budapest), or they are entertaining programmes themselves without any competition and primarily market-oriented programmes within a larger event. [e.g. in Hungary such a programme is the Art Expo Exhibition and Fair of Modern Arts within the Budapest International Fair.]

There are also competitions that happen to be organised in Hungary. For example, the Bocused'Or international culinary competition was hosted in Budapest in 2016.

The most popular artistic events entailing competition between the participant are currently the various thematic or 'give-your-all'-type talent shows. The talent shows attracting the largest audience are televised talent shows. One of the non-televised talent shows in Hungary is the National Folk Music Talent Competition, while televised talent shows include Konyhafönök, Hungary's Got Talent (a format copied from other countries), Virtuózok, which concentrates on classical music, and the Fölszállott a Páva series.

It can be seen that there is both a media demand and a social demand in a broader sense for an event of this type and even for it to be held regularly. Such long-term demands make it plausible that commercial aspects could be sustained, that the event would generate revenue and that it would have consistency. A detailed analysis of the reasons for this and the measurement of the popularity of the various talent shows is beyond the scope of this study, but this phenomenon ${ }^{7}$ is well-documented both in local and foreign publications and scientific literature. It is highly likely that a significant part of the viewpoints presented in the relevant studies could also apply in relation to an artistic mega-event that would also be accessible through national and international media.

3. Such an event could also give a platform to various artistic and folk-art fields specific to a certain area or country, thus providing its representatives with resources (sponsors) and new supplies. Furthermore, it could rejuvenate, develop and provide international recognition to various little-known or usually inaccessible creations. It can be stated therefore that in the broadest sense such an event would also have a function of preserving cultural heritage.

\footnotetext{
${ }^{7}$ In Hungarian see e.g. DomBóvÁRI Kristóf: Mitől jó egy tehetségkutató? (What Makes a Talent Show a Success?) Kreatív: Marketingkommunikációs szaklap 2015. 24(10), 30-31.; TRENCSÉNYI László: Kettős mérce? A "tehetségszakma" és a televíziós "tehetségkutató" műsorok (Double Measure? The 'professional talent scouts' and the televised 'talent shows'). Tehetség 2011. 19(3), 17. In English see AnDERS, George: The Secrets of the Talent Scouts. The New York Times, March 14, 2009. p. BU1.
} 
4. Adding this element could greatly improve the chances of a summer Olympics being organised in Hungary, since one of the most delicate and increasingly important ${ }^{8}$ questions in considering applications for the right to host the Olympic Games is the issue of post-Olympic usage of the materials and infrastructure, whether for sports or other purposes. There have been several poor examples in the last decade, in the case of several summer Olympics (e.g. Athens) and also winter Olympics (e.g. Sochi), as well as international football championships (e.g. the stadium built out of necessity for the Brazilian World Cup, which was transformed later into a bus garage). In relation to this project, the infrastructure that would be built directly or indirectly for sports purposes could be used without significant transformation and at almost no cost for the purpose of artistic, musical and other competitions, including the infrastructure, which could provide the proper conditions for the contestants, their entourage, fans, etc.

Although Hungary has withdrawn its bid for the 2024 Summer Olympics, ${ }^{9}$ its position as a competitor for the right to host a later Olympics would be significantly improved if it had already successfully organised a regular international cultural competition.

Naturally, an event such as an Olympic art competition, or an initial, smaller-scale variant thereof, (see Point 6 in this chapter) could be integrated directly into the summer (or winter) Olympic Games - first as an entertainment programme, and later as an independent event or one on the same level as the sport competitions.

5. It can be also stated that such an event would 'fit' Hungary well, since in the majority of the artistic fields in which participants would compete, Hungary occupies more significant international positions than would be expected according to its economic power, its territory or its population ${ }^{10}$, similar to its position in the field of sports. Its infrastructural development makes it suitable even at the present moment to efficiently organise an international event of this type, but of lesser importance than the Olympic Games.

It could be an advantage that the event would take place in a concentrated period, i.e. it would last only a few (four to six) weeks, ensuring consistent media interest, high intensity of the event and a number of competitions taking place at the same time (similar to the Olympics themselves). Chronological concentration could lead to a practical 'deconcentration' in terms of locations, namely it could be organised not only by one, but by several settlements (territorial units) if transport infrastructure, a high number of competitions, the existence of entertainment programmes, and financial and other considerations demanded it. In this respect, the Múvészetek Völgye Fesztivál (Valley of Arts Festival), which held its $27^{\text {th }}$ edition in

\footnotetext{
${ }^{8}$ See the Agenda 2020 reform programme of the International Olympic Committee (IOC).

9 'Given the break-up of the political unity', in March 2017 (when only three cities were still in competition), the General Assembly of Budapest, together with the Hungarian Olympic Committee, withdrew Budapest's bid for the 2024 Summer Olympics. Eventually, in October 2017, Paris was granted the 2024 Olympics and Los Angeles the 2028 Olympics. The direct cause for Hungary's withdrawal was an initiative for a referendum on the organisation of the Olympic Games.

10 Following the 2016 Olympic Games in Brazil, Hungary holds position no. 11 in the overall Olympic medal summary chart (which does not contain the results of the art competitions), with 501 medals won - this becomes ninth position if considering only states that still currently exist. This achievement far surpasses the results to be expected according to its international position based on territory, population, or economic development. In the 2016 Olympic Games, Hungary came twelfth in the medal summary chart and tenth according to medals per capita.
} 
$2017^{11}$, could be seen as a 'miniature' prefiguration of an Olympic art competition involving several towns at the same time. In Hungary's application for the organisation of the 2024 summer Olympic Games, competitions were planned to take place in nine other areas in addition to Budapest, with seven sports holding their entire competition, from the preliminaries to the medal ceremony, awary from the capital.

It must be emphasised that Hungary's tourism revenue is increasing continuously, and Hungary has a constantly improving position internationally. A specific tendency of the recent period is that competitions of a wider cultural but narrower artistic nature are particularly internationally-oriented and a money prize is more often attached. Recent examples include the latest international barbeque competition and the international cadence contest. ${ }^{12}$

6. Another advantage of such an event is that it does not need to be organised in its most extensive form from its first edition, but allows for planned building - rational extension according to capacity and resources. This means that, for example, the first edition could start out with competitions in eight to ten artistic fields and the next time the programme could be adapted and extended (or restricted) according to the practical outcomes of the first event and the demands formulated in the time between. An initial event in the style of a pilot programme would increase the probability of success.

An issue also related to Point 5 of this chapter is the frequency with which the Olympic art competition could be organised. Yearly organisation or every five years could both be rationally justified depending on the number of artistic fields (competitions) and the sporting or other events with which overlapping needs to be avoided. Of course, the frequency would depend also on financial conditions (commercial, merchandising and other) and on consideration of specific characteristics of the various artistic fields.

\section{POSSIBLE DOMAINS (ARTISTIC FIELDS FOR COMPETITIONS)}

We shall now review the eligible artistic fields, i.e. those that are generally (internationally) known and therefore suitable for a notable competition between creations or performances. As will be discussed, practically all known artistic fields are eligible and all have valid, existing examples of competitions. An overview of the key artistic fields follows below.

1.Graphic arts - with several individual subdivisions (classical industrial art, painting, sculpting, numismatic art, fabric art, media art) and tangent fields (body painting, performance, intermedia etc.).

2. Music and singing - with several independent subdivisions.

3. Dance, theatrical art and the art of motion - with several independent subdivisions.

4. Culinary art.

\footnotetext{
11 The Müvészetek Völgye Fesztivál (Valley of Arts Festival), which today spans several towns, started in Kapolcs, a settlement in the northern part of Lake Balaton, at the end of the 1980s. In the time since, the festival has become settled in seven localities: Kapolcs, Vigántpetend, Taliándörögd, Monostorapáti, Öcs, Pula and Nagyvázsony. Every year the festival is organised at the end of July and the beginning of August and it lasts for a week. It consists of theatrical performances, classical, folk and pop music concerts, literary panels, exhibitions and presentations of various crafts.

12 13-15 October 2017 marked the first official, scoring barbeque competition with an actual money prize (Master Series Sanctioned Contest) in Hungary, under the patronage of KCBS - Kansas City Barbeque Society. The competition was held in the heart of the Tokaj wine region, in Tállya. Its accompanying programme was a large blues and wine festival. 3-7 May 2017 were the dates of a cadence competition in Buda called Beethoven at Buda with a money prize. It was run by the Municipality of Budavár took, and the organisers requested works composed for the first, second and third movements of Beethoven's Violin Concerto in D Major.
} 
5. Film and photography - with several independent subdivisions.

6. Architecture.

7. Circus arts.

It is worth mentioning that this categorisation is not an exhaustive or objective one. There are no clear dividing lines as artistic fields are permeable, e.g. photography could also be placed under Graphic Arts and body painting/performance genres could be included in Dance/Theatrical art.

The opportunity of 'permeability' opens the way for competitions in new, mixed artistic fields even in the form of competition fields that have not been seen previously but may be more effectively broadcast by the media.

It is also important to note that, within certain 'traditional' fields, considering the special interests of the contestants or public demand or other viewpoints, subdivision competitions or competitions with restricted participation could be organised. This could be similar to athletics, which is a sport with five elements (running, walking, jumping, throwing and mixed competitions) and many competitions within each section. Similar to competitions within certain sports, it could be possible to 'count' the same performance several times (as an individual result and included in the result of possible team competitions). In the competition regulations of each art competition it should be established whether the competition should be between individuals, pairs or teams (see Chapter $\mathrm{V}$ regarding the preferred content of the regulations).

\section{THE MAIN CHARACTERISTICS, DOMAINS AND TASKS OF THE SCIENTIFIC RESEARCH CONDUCTED TO ACHIEVE THE OBJECTIVES SET \\ Particularities of the scientific research related to the feasibility of Olympic art competitions}

The primary research types used in economic and technical fields (and especially wellinterpretable in those fields) are basic research, applied research and so-called exploratory development. Such a classification has its grounds also in political science and jurisprudence and in the field of economic sciences, as well as social sciences in general. Contrary to basic research, which is research without a concrete application and utilisation field, applied research is always an original enquiry aiming to acquire new knowledge, mainly for concrete, practical objectives, applied to existing institutions. For example, research in 'applied jurisprudence' can be considered research that analyses and evaluates legislation and/or the application of laws. Exploratory development however, is a regular occupation based on knowledge learnt from research and practical experience whose aim is the creation of new 'products' - introduction of new procedures, complex systems and services, and continual development of the main elements of the products thus created or introduced to the market.

Research related to the feasibility of the Olympic art competitions - and the circle of legaladministrative and other underlying and background studies as part thereof - resembles mostly the third research type. The presented studies are needed not only to outline a practical aim of a 'product' that doesn't currently exist, but also to consider the later necessary and continual development of the product in a manner that evolves during a longer period and results in content extension. Such research aims at the creation and possible further development of an innovative product intended for the market, as was mentioned in the introduction. 


\section{Scientific fields integrated into the proposed research}

This study has as its objective the creation of the possible and desired contents of a social phenomenon (system) which does not yet exist. In this case, to access new information it is certain that the following will be needed:

1) Cataloguing of the relevant scientific fields for the study of this matter;

2) Selection of the relevant methods grounding some of the general principles and the concrete regulations (observation and comparative study of existing competitions, surveys among the potential participants and media consumers, etc.);

3) A strongly inter- and multi-disciplinary approach to the practical research; and

4) Prior establishment and repeated confirmation in the course of the research of the viewpoints which make the results of the study acceptable and actually usable by the 'client'. The client in this case could be the state, a public-private partnership (e.g. a public body), or a capitalised profit-oriented market participant undertaking the organisation and/or financing of the project.

\section{Which scientific fields are required for such research?}

We begin by considering that the fact that most of the issues related to such a project can be formulated mainly by the most exact social and international norm type, the language and instruments of the law. Legal tasks are not confined only to the significant number of contracts signed in such cases, or to the phrasing of unilateral declarations or familiarity with the legaladministrative field related to the participants and the event. Even professional and content requirements related to the competitions within each artistic field and the competition regulation itself needs to be phrased in legal terms. It is therefore important that the first scientific fields to be considered for this research should be jurisprudence (more specifically legislation, copyright law and performing artists' law as more or less autonomous disciplines) and administration science (more specifically management of artistic life, financing of artistic events through the tax system and disciplines within law enforcement).

Using the legal field means primarily finding the correct form of expression. It serves the presentation in a unitary and accessible form of the professional, content-related rules of each artistic field, since these rules must be established in writing, considering that this is a competition. However, the scientific study of content matters and the phrasing of specific proposals related to these is the task of art history ${ }^{13}$, while processing at a scientific level the values of a certain artistic field related to the competitions in that field is the task of the relevant subdisciplines (e.g. music history, architectural history).

Alongside a scientific presentation of the artistic, professional, legal and administrative perspectives regarding the competitions, the research methods and results of other social sciences, such as political science, administrative science (organisation and leadership theory; general and specialised organisation studies, specifically the fields of cultural and sport organisation), public policy sciences, tourism sciences, media sciences and even sport studies in their broadest sense can significantly contribute to the creation of a complex feasibility study. The fact that, in the modern world, more traditional methods are complemented with network theory approaches, more suitable for the analysis of a globalised world, should be given special emphasis.

\footnotetext{
13 Related to the self-image and objectives of Hungarian art history; see for example Marosi Ernő (ed.): $A$ magyar müvészettörténet-írás programjai (Programs of Hungarian Art History Writing). Corvina, Budapest, 1999.
} 


\section{Main tasks of the scientific work}

Three tasks, or roles, can be identified as necessary for the preparations based, among other things, on the methodology and concrete results of the scientific field (i.e. during the drafting of the scientific part of the basic and background studies and of the various regulations). One of the premises of a successful research process is that the principles and participant researchers in each field of action should be clearly defined. Thus, the three tasks are:

- General project management tasks. These include selection of the authors and researchers for each particular field, continual communication of the general professional standards, concrete requirements and viewpoints to be taken into consideration and compilation of the (sub)studies and editing thereof into a coherent, unitary material (coordination tasks);

- Preparation of the special studies grounding and facilitating the feasibility of the project, e.g. marketing plan, tourism plan, the study dealing with copyright (utilisation) issues $^{14}$, the study disclosing administrative links ${ }^{15}$ etc.; and

- Collaboration in the field of preparation and phrasing of concrete regulations regarding the various artistic fields and art competitions. This activity requires a sound knowledge of the features of the particular artistic fields and experience in regulating such competitions.

\footnotetext{
14 The clarification of some preliminary questions also falls under this task, such as whether the expressions 'Olympics' or 'Olympiade' are patented in Hungary or internationally and what limitations need to be observed (e.g. for the purposes of differentiation of this event from other organisations and activities that usually use the expression 'Olympics'). Even if this expression could be legally used, it would be recommended to 'create' an appealing and translatable designation. This could also be done at a later stage, perhaps even with a naming contest, which would also promote the event. The preliminary proposals of Mrs. Júlia Téglási Kovács are ARTLIMPIA, ARTPLIMPICS and, specifically for the field of music, the expression MUSICALIMPIA.

15 The term 'administrative links' covers primarily the issues related to the support of the artistic domain in general and to the support by the local authorities of such a 'mega-event' in particular. The task would be drawing up a complex administration-centred feasibility study, which would catalogue the fields and aspects that make it possible or even necessary for the local administration to undertake a role in the organisation of the event (as a legislator, service provider, organiser etc.), and would also detail to a certain extent these fields formulating even proposals besides presenting the effective regulation framework. Such aspects could be (not exclusively):

1. Phrasing proposals regarding the completion and coordination of tourism-related governmental tasks. A novelty in this domain is that, as of 2016, tasks related to tourism would be assigned to a single institution, i.e. to the Ministry for National Development by creating a new organisation, the Hungarian Touristic Agency. One of the motives for centralisation was that there was no 'unitary general national view on tourism' despite the increasing touristic activity in the country and thus directions for development and target-groups had not been defined. The element of these changes affecting the Olympic art competition is that, due to information, plans and the corresponding resources being centralised to one spot, tasks related to such 'events of national importance' can be achieved more efficiently in the future.
}

2. Obtaining the permits necessary to organise and hold events (what is necessary, what is not and where could the process be simplified).

3. Regulations regarding bringing goods into the country and taking them out (many things could be affected by this, from musical instruments to artworks made at the competition). Besides delineation of the present situation, it would be ideal to take the matter to phrasing of proposals and observations.

4. Looking for direct fundraising opportunities, i.e. those offered by the state budget or various grants.

5. Review of opportunities for the indirect financial support of the state, i.e. provided through the tax system. This means considering the system of tax deductions and also the amendment handed in and approved at the beginning of 2016 regarding sponsorship of artistic activities, which provides that there is also an opportunity to benefit from tax deductions related to financial support of the Olympic grant (see provisions of Act no. LXXXI of 1996 on corporate tax and dividend tax and of Act no. II of 2016 modifying the provisions of Act no. I of 2004 on sport). Obviously, such an institutionalised solution would greatly facilitate the organisation and administration of an Olympic art competition as well.

6. Review of visa and other administration matters of the participants, leading to proposals aiming to obtain simplified procedures. Necessarily, aspects of alien police activity will also be taken greater account of in this case. 
If there are clearly defined 'client' requirements and experienced collaborators, some of the roles can be contracted. However, one of the guarantees of quality for conceptions and substantive regulations is the active participation of several contributors in their phrasing.

\section{THE CONTENT OF THE DRAFTS AND REGULATIONS AND THE PROCESS OF DRAFTING}

Definition of the essential frames (conditions) in respect of all the artistic fields and art competitions is necessary for the drafting of the general (common) rules regulating all the fields and competitions and of the particular (specific) rules regarding the individual art competitions.

It must be emphasised that scientific grounding and establishment of the possible competitions and the phrasing of the competition regulations should be a congruent process, where political decisions, (e.g. regarding the extent to which the state plays a role), legislative grounds, scientific and other type of studies and calculations and continual synchronisation with the possible organisers, artistic actors, financers, administrators or future audience embody a constructive progress of mutual consideration.

Within the present study no proposal will be made on what the specific competitions or financing alternatives should be. This paper will mentioned only those general preliminary issues which should be regulated in the case of all competitions, even if the specific content will vary.

Assuming a prior political decision, concurrently with establishment of the competition events material needs to be drafted which will present the approximate number of participants (competitors and other collaborators), the manner of their selection ${ }^{16}$, the manner(s) of implementation of the competitions (with the necessary, but not exhaustive, details), an estimate of the necessary infrastructure, an estimate of the necessary materials and other resources, and a presentation of how these conditions will be provided.

Issues regarding competitors, e.g. creation of amateurism or setting it as a criterion, (whether this category can be interpreted somehow in this case; whether it is justified to exclude an artist from the competition due to one of their existing contracts), or a potential justification of formulating some conditions regarding age or other characteristics of the potential participants, also need to be thought over.

Another important preliminary question is whether the theme of the artworks created in the various artistic fields should be related to sports or to phenomena closely related to sports (e.g. friendship, solidarity, collaboration etc.). The possibility of creating a thematic Olympic art competition is strengthened by the fact that sport has been committed to interconnecting various nations and individuals, despite sometimes significant differences in culture, religion, economic development etc., since the beginnings of the Olympic movement. An Olympic art competition, as a movement, would also need to undertake values such as solidarity, fighting against social discrimination or raising awareness of environmental protection issues. One

\footnotetext{
${ }^{16}$ In this respect a decision should be taken about matters such as whether participants would be selected based on invitation (of a specific person, production, maybe the right of a certain country to bring a certain number of competitors) or on individual application. If the right to participate were linked to a certain organisation in the various countries, then there is also a possibility for national (regional, continental etc.) qualifying rounds and preselections to be held. Issues like establishment (necessity) of a competition entry fee obviously depends on who the organiser and administrator will be, what financing construction is established and the awarding structure of the competition.
} 
example of the results of this approach is the initiative of the International Olympic Committe at the 2016 Olympics in Rio that allowed athletes who had refugee status to attend as independent Olympic participants.

The main requirements regarding administrative plans (conceptions) and concrete regulations of the various competitions are listed below.

- Rules should be simple, meaning that a presentation of the administration that is easily understood and transparent for spectators needs to be produced.

- No, or minimal, new investment in infrastructure should be required for the organisation of the competition.

- As far as possible, the whole or most of the competition should be television- and media-compatible, i.e. broadcastable.

- If possible, the whole or most of the competition (possibly several of its elements) should be spectator-friendly, meaing that it should be possible to follow and enjoy the evolution of the competition (e.g. the performance, the formation of the artwork etc.). One of the key elements of spectator-friendliness is active participation of the spectators and interested parties in as many domains of the various competitions as possible, including in the decision-making process (qualification, establishment of placing). However, the active (interactive) forms of participation may not undermine the seriousness of the competition or become an end in themselves, and especially must not significantly increase the organisational and administrative burden related to the event.

- Provision of comparability of the various artistic performances and creations is a central issue. Formulating the criteria of measurability and strengthening the objective element is one of the keys to the credibility of the entire event. For example, it may be agreed that first, second and third places shold not be awarded, but rather qualifications, (e.g. gold, silver, bronze), and that several awards could be assigned within each category of qualification.

- Regulations should provide guarantees for the transparency and civilised conduct of the competitions (employment of jurors, alcohol or drug tests if needed etc.).

- How this competition is similar to or different from comparable events is a useful control question. The main idea is not to differ in all areas, but to have fresh, original new ideas and organisational and awarding novelties, which would arouse the interest of famous, well-known artists, artistic colonies or formations enough that they would wish to participate.

- International models and exemplary features of similar events should be taken into consideration in the course of drafting. Comparison with existing practices (even with specific regulations, organisational charts) provides a certain professional control and makes taking on or consciously improving upon existing schemes and best practice possible.

- In the case of all drafts, when a certain level of readiness is achieved, the inclusion of several 'reference persons' is recommended. This means experts in the relevant fields who have already participated at a professional level in the preparation, organisation, administration, financial management or regulation planning of events and programmes in those fields. Obtaining a professional opinion from such a person makes elementary mistakes avoidable and provides a more clearly constructed draft.

The above points (especially the final two) are worth observing not only in the course of drafting the general regulations, but also in formulating the special studies (see Subpoint I.1.) grounding the regulations and supporting and facilitating their feasibility. 


\section{CONCLUSION}

The present study raises the idea of creating an artistic Olympics to facilitate further scientific, professional and, where approriate, broader social dialogue, considering two dimensions.

Firstly, the study supports the realisation of an event of this type in Hungary by articulating valid arguments, emphasising those elements that would make Hungary an ideal host/organiser.

Secondly, the study offers indicators for further, more thorough. scientific consideration of the process by outlining the main research directions and methods.

It is particularly worth mentioning in conclusion the arguments given to support the organisation of an 'Artistic Olympics' in Hungary.

- The duration of the 'Artistic Olympics' would be not only two weeks, but a longer period of time, providing a more balanced infrastructure and a better return for the host community or communities. It could be repeated in the same locations, or it could operate as a franchise - the possibilities are almost unlimited. The frequency of the program could be adjusted to address real needs and opportunities.

- It would not operate based on a 'main programme - accompanying programme' structure, due to which isolated, narrow artistic fields (targeting a distinct audience) being given little media attention. As a result of the unified concept and the common PR, meaningful attention could be brought to every artistic field.

- It could be constantly developed, meaning that the programme does not have to be initially launched in a completely developed version. It could be started as a pilotproject with a limited number of artistic fields as an experiment. Then, with the accumulated experience, it could be developed proportionately and be supplemented with additional competition fields.

- A country (or city) that is hoping to be a candidate for hosting the Olympics (or other world-class events) could draw attention to itself by hosting an event like this, and prove its commitment towards culture as well as its multi-faceted organisational abilities to a wide audience.

\section{References}

AnDERS, George: The Secrets of the Talent Scouts. The New York Times, March 14, 2009. p. BU1.

DomBóvÁRI Kristóf: Mitől jó egy tehetségkutató? (What Makes a Talent Show a Success?) Kreatív: Marketingkommunikációs szaklap 2015. 24(10), 30-31.

Findling, John E. - Pelle, Kimberly D.: Encyclopedia of the Modern Olympic Movement. Greenwood Press, Westport. 2004.

KERESZTÉLYI József: Az Olimpiák története - Az Olümpiától Moszkváig (The History of the Olympic games - from Olympia to Moscow). Gondolat Kiadó. Budapest, 1980.

LÉVAI György-IVANICS Tibor: Az újkori olimpiák története: 2. rész (1920-1936) (The History of the Modern Olympic Games. Part 2. 1920-1936). Kossuth Kiadó, Budapest, 2011.

MARosi Ernő (ed.): A magyar művészettörténet-írás programjai (Programs of Hungarian Art History Writing). Corvina, Budapest, 1999.

TAKÁcs Ferenc: Az Olimpiák - múltja, jelene, jövője (The Olympic Games - Past, Present and Future). Magyar Olimpiai Bizottság. Budapest, 2012.

TRENCSÉNYI László: Kettős mérce? A "tehetségszakma" és a televíziós "tehetségkutató" műsorok (Double Measure? The 'professional talent scouts' and the televised 'talent shows'). Tehetség 2011. 19(3), 17. 